\title{
From soft power to reputational security: rethinking public diplomacy and cultural diplomacy for a dangerous age
}

\author{
Nicholas J. Cull ${ }^{1}$ (1)
}

Revised: 10 September 2021 / Accepted: 20 September 2021 / Published online: 6 November 2021

(c) The Author(s), under exclusive licence to Springer Nature Limited 2021

\begin{abstract}
This paper identifies four rhetorical strategies used during the COVID 19 pandemic by communicators associated with nation states to either enhance their own security through protecting or improving their reputation or to diminish that of a competitor or rival. These strategies are: praising the self; criticizing the other; engaging others through gifts and a strategy of multilateral cooperation. The examples cited come chiefly from March and April 2020 revealing how early the key communication strategies solidified. The piece notes preliminary evidence of reputational impact with slippage in the standing of the USA and a major drop in the standing of China visible in the Nation Brands Index and other polls. It concludes with an endorsement of cooperation/collaboration as the optimal strategy to use not only against COVID but in the face of other transnational challenges too.
\end{abstract}

Keywords COVID diplomacy $\cdot$ Reputational security $\cdot$ Strategies of public diplomacy $\cdot$ US-China relations $\cdot$ International image

It is the nature of pandemics that international relations, reputation, and health become intertwined. Looking back on the epidemic of 1665 from the vantage point of 1722, British novelist Daniel Defoe commented on this. The narrator of Defoe's Journal of the Plague Year complains about the damage done to Britain's international image by competitors from the Netherlands who not only exaggerated news of the plague's impact to win over Britain's customers in the Mediterranean, but also bought cheap stocks of British goods and sold them on as Dutch (Defoe). The twenty-first century has similar dynamics. Nations increasingly use multiple communication strategies to maximize their advantage and the pandemic provided scope for this. The experience of COVID 19 demonstrated the extent to which the world has moved on from the relatively benign international storytelling of the post-Cold War era in which attempts to boost one's soft power were a side issue for the wealthiest countries. With reputation now actively contested the process of building soft power has become a multifaceted struggle to establish

Nicholas J. Cull

cull@usc.edu

1 University of Southern California, Los Angeles, USA and protect each actor's reputational security (Cull 2019 and forthcoming).

The information battles of the pandemic have thrown up four core strategies: praising the self; criticizing the other, engaging others through gifts and a strategy of multilateral cooperation. These also became tropes in media coverage of the crisis and one issue in analyzing messaging during the pandemic is the game of attempting to deduce which media statements had governmental weight behind it and which was simply noise. The examples cited come chiefly from March to April 2020 revealing how early the key communication strategies solidified.

\section{Strategy 1: The self as success}

Pandemic communication began with self-praise. China set the tone early in 2020 when it was the main country responding to the outbreak with a string of stories designed to show the competence of the central government. Associated narratives include stories highlighting heroism of medical personnel and resilience of the wider population. Beijing paid a special attention to the rapid construction of hospital in Wuhan in just ten days (Xinhua, February 2020). Japan made the restoration of a global image for competence in 
the pandemic a particular goal including investment in AI to monitor the county's image in real time (Denyer 2020). By April 2020, Washington DC was a media battleground with Saudi Arabia and South Korea adding Covid 19 competence stories to their existing lobbying campaigns (Lehren et al. 2020).

There is an obvious problem with this 'self as success' strategy: what Francis Bacon termed the 'hostages to fortune'. A claim made early can attract attention to a disaster in the making and become a dictionary definition of hubris. Publics have a way of perceiving these claims even if they were not made, as the British cultural historian Richard Howells has shown the Titanic was called 'unsinkable' only after it sank (Howells 1999). Missteps were made worse by the second major strategy: other countries accentuating your negatives.

\section{Strategy 2: The other as failure}

For the strong-man politicians of the 2020s highlighting the failures of international comparators seemed a reflex whether for domestic audiences or those abroad. President Trump could not resist pointing to the high per-capita death toll in Belgium (Schultz 2020). China and the USA traded rhetorical blows. Trump lost no opportunity to link the virus to China. In March 2020, Secretary of State Mike Pompeo held up signing a joint communique on the crisis by the G7 leaders because he wanted to refer to the "Wuhan virus" (Hudson et al. 2020). China's foreign ministry's spokesman Zhao Lijian, tweeted a rumor that the US Army had introduced the Covid 19 virus into Wuhan in October 2019 during their participation in the World Military Games (Zheng 2020).

For some international actors, the crisis provided an opportunity to circulate disinformation crafted to undermine confidence in others. Russian outlets stoked fear of vaccines and alleged, among other things, that the virus was a US bio-weapon. Kremlin-media portrayed Bill Gates as mastermind of a virus conspiracy and repeated tendentious stories from Iran and China in a self-reinforcing cycle of distortion Woodruff Swan 2020 and Barnes et al. 2020). By the end of April 2020, the EU was actively denouncing disinformation in both Russian and Chinese communication (Beaumont et al. 2020).

Some saw rhetorical hostility as unwise. Diplomats seeing to calm tempers included Cui Tiankai, the Chinese Ambassador to the US, who in late March 2020 dismissed stories of a US lab as the origin as 'crazy' and deliberately distanced himself from his own foreign ministry's spokesman (Zhou 2020). A gentler strategy of the gift proved possible even between adversaries even if it was not necessarily effective.

\section{Strategy 3: The gift}

Gifts - public diplomacy of deeds-were an early response to Covid 19 as South Korea and Japan presented medical aid to China. Twin cities marked existing relationships with donations of money or supplies. Some gifts drew additional rhetorical signals. The Chinese Foreign Ministry accepted Japan's gift with a quotation: 'You throw a peach to me, I give you a white jade for friendship.' Such gestures had both an inherent message of escalating good feeling and referenced a world of shared East Asian values and culture to the exclusion of other nations ( $\mathrm{Li}$ et al. 2020).

Other examples of gifts which were well received included a loan of volunteer medical personnel by Albania to Lombardy in Italy. 30 doctors and nurses in late March 2020 and 60 more nurses in mid-April 2020 (Balkan Insight 2020). Part of the good feeling generated by Albania's gift seems to have come from the asymmetry of power and wealth between Albania and Italy. China's gifts - in contrast - had a different power dynamic and were read in a context of the country's well-known strategies of global engagement. Audiences were on the lookout for a mixed motive (Dunst 2020).

\section{Strategy 4: Partnership}

For all the attempts of nations to speak, the virus had the loudest voice. The transnational pandemic emphasized the need for transnational collaboration and provided opportunities for countries to associate themselves with collective solutions. The obvious forum for partnership was the World Health Organization. Early contributors included Finland, which in April 2020 further increased its funding to $€ 5.5$ million to help offset the unilateral funding cut announced by Donald Trump (Xinhua April 2020). In May 2020, the European Commission's Coronavirus Global Response International Pledging Conference raised $\$ 8$ billion for the collective fight against the virus (Richter 2020). The British Prime Minister Boris Johnson, as co-host and a high-profile virus survivor, spoke powerfully of the need for cooperation: 'It's humanity against the virus-we are in this together...' (Prime Minister's Office 2020).

There is plainly a reputational benefit in being seen to be part of this kind of collaboration and, by this same token, reputational damage to be done when international actors refuse to collaborate or emphasize unilateral gain. Russia, India, and Trump's USA stayed away from the EU conference. China took part only after much persuasion and then only via its ambassador to the EU while others 
were represented by their heads of government (Wintour 2020; Booth et al. 2020). Collaboration was, however, a theme in Chinese digital diplomacy. Chinese London embassy tweets analyzed by Marcel Schliebs of the Oxford Internet Institute included memes about collaboration like Ambassador Liu Xiaoming's use of the British proverb 'a friend in need is a friend indeed,' which received special amplification from Beijing's network of 'inauthentic user' re-tweeters (Schleibs 2021; Schliebs et al. 2021).

The web of words and actions around vaccination became an extension of this struggle over a multilateral mindset. Early damage to the US reputation came when in March 2020 President Trump attempted to acquire exclusive access for the US to a potential vaccine being developed by the German company CureVac (Bennhold et al. 2020). Once the vaccine became available some countries worked to collaborate on global distribution through the COVID-19 Vaccines Global Access program (COVAX) (Desaraju et al. 2021). Others operated through variations on the rhetorical strategies road-tested in the early months of the pandemic, praising their own vaccines, criticizing others (and the attitudes to vaccines displayed by their own populations) and seeking friends through generous vaccine deliveries.

\section{The reckoning?}

Long-term observers of international reputation understand that reputations are neither made nor lost overnight. Dramatic movement in scientifically measured indices of soft power such as Simon Anholt's Nation Brands Index is rare and hence it was noteworthy that the 2020 version of the NBI published in October 2020 revealed a dramatic collapse in the international image of China, which plunged from a habitual place in the mid-20s to a place below India in the mid-30s. The USA continued the easing back in its reputation seen during the Trump period. Beneficiaries included New Zealand, which figured in the top five most admired political systems, South Korea, which moved up a couple of spots and Canada, whose positive moves in endorsing collective responses were an obvious contrast to its neighbor to the South. Germany remained the most admired overall, despite a lackluster response to the pandemic, indicating that COVID was just one element in overall perception (McGrath 2020). Time will tell if the reputation of entire regions is in flux. The success of socially cohesive eastern actors like South Korea or Taiwan contrasts with the failures evident in many western countries where citizens have questioned the need to surrender personal liberties for the collective benefit. It may yet be that the reputational security of the western democracies as a whole will be damaged as a result.

\section{References}

Anholt, Simon. 2021. Conversations with author.

Balkan Insight. 2020. Albania sends 30 doctors to help Italy fight corona virus, March 28. https://balkaninsight.com/2020/03/ 28/albania-sends-30-doctors-to-help-italy-fight-coronavirus/. Accessed 10 Sept 2021.

Barnes, Julian E., Matthew Rosenberg and Edward Wong. 2020. As virus spreads, China and Russia see openings for disinformation. New York Times, March 28.

Beaumont, Peter, Julian Borger and Daniel Boffey. 2020. Coronavirus sparks perfect storm of state led disinformation. Guardian, April 24.

Bennhold, Katrin and David E. Sanger. 2020. U.S. Offered 'Large Sum' to German Company for Access to Coronavirus Vaccine Research, German Officials Say. New York Times, March 15.

Booth, William, Carolyn Y. Johnson and Carol Morello. 2020. The World comes together for a virtual vaccine summit... Washington Post, May 4.

Cull, Nicholas J. 2019. Public diplomacy: Foundations for global engagement in the digital age. Cambridge: Polity.

Cull, Nicholas J. forthcoming. From soft power to reputational security: Rethinking public diplomacy and cultural diplomacy for a dangerous age. In The Routledge Handbook of Diplomacy and Statecraft, 2nd edition, ed. B.J.C. McKercher. London: Routledge.

Defoe, Daniel. 1722. A journal of the plague year. London: Nutt

Denyer, Simon. 2020. Japan sets aside \$22 million to buff government's global image amid pandemic struggles. Washington Post, April 15.

Dasaraju, Srividya, Sahit Menon, Sameer Nair-Desai, Hailey Robertson. 2021. Winning hearts \& minds through a shot in the arm. CPD Blog, April 21. https://uscpublicdiplomacy.org/blog/winni ng-hearts-minds-through-shot-arm. Accessed 10 Sept 2021.

Ducarme, Denis. 2020. tweet from @ ducarmedenis) sent April 20, 2020. https://twitter.com/ducarmedenis/status/125247828083549 7987. Accessed 10 Sept 2021.

Dunst, Charles. 2020. How China's mask diplomacy backfired. American Interest, April 15. https://www.the-american-interest.com/ 2020/04/15/how-chinas-mask-diplomacy-backfired/. Accessed 10 Sept 2021.

Howells, Richard. 1999. The myth of the titanic. London: Palgrave.

Hudson, John and Souad Mekhennet. 2020. G-7 failed to agree on statement after U.S. insisted on calling coronavirus outbreak "Wuhan virus". Washington Post, March 25.

Li, Cheng and Ryan McElveen. 2020. Mask diplomacy: How coronavirus upended generations of China-Japan antagonism. Brookings Institution Blog, March 9. https://www.brookings.edu/blog/ order-from-chaos/2020/03/09/mask-diplomacy-how-coronavirus-upended-generations-of-china-japan-antagonism/. Accessed 10 Sept 2021.

Lehren, Andrew W. and Dan De Luce. 2020. Foreign governments use U.S. lobbyists to promote their efforts fighting the coronavirus outbreak. $N B C$, April 2. https://www.nbcnews.com/politics/ national-security/foreign-governments-hire-u-s-lobbyists-promo te-their-efforts-fighting-n1174836. Accessed 10 Sept 2021.

McGrath, Jason. 2020. Germany retains top nation brand ranking... Press Release, IPSOS.com, October 27, https://www.ipsos.com/ en-ca/news-polls/Germany-Retains-Top-Nation-Brand-Rankingthe-United-Kingdom-emerges-ahead-of-Canada-to-Round-Outthe-Top-Three-US-and-China-Experience-Significant-Decline. Accessed 10 Sept 2021.

Prime Minister's Office. 2020. PM: 'It's humanity against the virus. Press Release, 10 Downing Street, May 4. https://www.gov.uk/ government/news/pm-its-humanity-against-the-virus. Accessed 10 Sept 2021. 
Richter, Felix. 2020. World Leaders Pledge \$8 Billion to Fund COVID19 Response. Statistica.com, May 5. https://www.statista.com/ chart/21603/initial-contributions-pledged-by-co-chairs-of-thecoronavirus-global-response-initiative. Accessed 10 Sept 2021.

Schliebs, Marcel. 2021. Correspondence with author.

Schliebs, Marcel, Hannah Bailey, Jonathan Bright, and Philip N. Howard. 2021. China's Public Diplomacy Operations: Understanding Engagement and Inauthentic Amplification of PRC Diplomats on Facebook and Twitter, Oxford Internet Institute/Democracy and Technology Working Paper, 2021/1, May 11, https://demtech.oii. ox.ac.uk/wp-content/uploads/sites/127/2021/05/Chinas-PublicDiplomacy-Operations-Dem.Tech-Working-Paper-2021.1-4.pdf. Accessed 10 Sept 2021.

Schultz, Terri. 2020. Why Belgium's death rate is so high. NPR, April 22. https://www.npr.org/sections/coronavirus-live-updates/2020/ 04/22/841005901/why-belgiums-death-rate-is-so-high-it-countslots-of-suspected-covid-19-cases. Accessed 10 Sept 2021.

Wintour, Patrick. 2020. World leaders pledge 74 bn Euros to research COVID 19 vaccine. Guardian, May 4.

Woodruff Swan, Betsy. 2020. State report: Russian, Chinese and Iranian disinformation narratives echo one another, Politico, April 21. https://www.politico.com/news/2020/04/21/russia-china-irandisinformation-coronavirus-state-department-193107. Accessed 10 Sept 2021.
Xinhua. 2020. China builds new hospital in 10 days to combat coronavirus, February 2. http://www.xinhuanet.com/english/2020-02/ 02/c_138750288.htm. Accessed 10 Sept 2021

Xinhua. 2020. Finland to increase its funding for WHO... Xinhuanet. com, April 16. http://www.xinhuanet.com/english/2020-04/16/c 138979546.htm. Accessed 10 Sept 2021

Zheng, Sarah. Chinese foreign ministry spokesman tweets claim... South China Morning Post, 13 March.

Zhou, Viola. 2020. Corona virus barbs help nobody, China's Washington Ambassador, South China Morning Post, March 23.

Publisher's Note Springer Nature remains neutral with regard to jurisdictional claims in published maps and institutional affiliations.

Nicholas J. Cull is professor of Public Diplomacy at the University of Southern California. He is a historian and analyst of the role of communication in foreign policy. His most recent books include Public Diplomacy: Foundations for Global Engagement in the Digital Age (Polity, 2019) and (co-edited with Michael Hawes) Canada's Public Diplomacy (Palgrave, 2021). 